\title{
Prevention Practice and Associated Factors of Coronavirus disease 2019 (COVID-19) Outbreak among Educated Ethiopians: An online Based Cross-sectional Survey
}

Henok Dagne ( $\nabla$ enoch2313@gmail.com )

University of Gondar

Kassahun Alemu Alemu

University of Gondar

Baye Dagnew

University of Gondar

Demewoz Taddesse

Ethiopian National Blood Bank Service

Abiy Maru Alemayehu

University of Gondar

Zewudu Andualem

University of Gondar

Dagnachew Eyachew Amare

University of Gondar

\section{Research Article}

Keywords: COVID-19, educated Ethiopians, Ethiopia

Posted Date: June 10th, 2020

DOI: https://doi.org/10.21203/rs.3.rs-34504/v1

License: (a) (1) This work is licensed under a Creative Commons Attribution 4.0 International License. Read Full License 


\section{Abstract}

Background: An acute respiratory disease, known as the novel coronavirus disease 2019 (COVID-19), was identified in the late 2019. As launched by World Health Organization, it is now a pandemic problem. So far there is no any vaccine or drug for treatment to this disease. The world including Ethiopia have been relying on practicing different preventive measures. As of 17-Apr-2020, the Ethiopian health minister reported 96 confirmed cases and 3 deaths of COVID-19 from the total of 6231 laboratory tests conducted. The mainstay of approach to avoid COVID19 is applying preventive measures. Therefore, the current survey aimed to assess self-reported measures of prevention practice and associated factors regarding COVID-19 among educated Ethiopians in the early stage of this outbreak.

Methods: An online based cross-sectional study was conducted to collect information from educated Ethiopians during the early stage of the outbreak from March 25 to April 4, 2020. Electronic based questionnaire developed by reviewing literature and revising from "COVID-19 Snapshot Monitoring comprised monitoring knowledge, risk perceptions, preventive behaviors, and public trust in the current coronavirus outbreak. Data were analyzed using SPSS-25. Results were presented using descriptive and inferential statistics. To determine predictor variables for preventive practice, a binary logistic regression model was fitted. Variables with a $p$-value $<0.05$ in the final model were declared as predictors.

Results: Five-hundred and twenty-eight Ethiopians participated in this study of which $80.7 \%$ were males. The mean age of study participants was $33.2( \pm 7.4)$ years. Above one-third $(34.7 \%)$ of the participants had a health-related profession. Majority (79.7\%) of the respondents attended degree and above education. Overall, above half (55.9\%) of the study participants had good knowledge about COVID-19. About 55.3\% and 57.8\% had good knowledge regarding symptoms and prevention methods of COVID-19, respectively. Overall, above half (54\%) of the respondents had good COVID-19 preventive practice. Being female [Adjusted Odds Ratio (Adjusted Odds Ratio): 2.00; 95\% Cl $(1.14,3.50)$ ], higher age (aged 33-37 years [AOR: 1.98; 95\% Cl $(1.01,3.87)$ ] and 38-72 years [AOR: 2.60; $95 \% \mathrm{Cl}(1.33,5.10)])$, good knowledge of symptoms [AOR: $2.82 ; 95 \% \mathrm{Cl}(1.85,4.31)$ ], good knowledge of prevention methods [AOR: $4.55 ; 95 \% \mathrm{Cl}(2.92,7.10)]$, having sufficient knowhow to protect self [AOR: $1.83 ; 95 \% \mathrm{Cl}(1.14,2.96)]$ and belief of presence of re-infection [AOR: $1.86 ; 95 \% \mathrm{Cl}(1.03,3.38)$ ] were significantly associated with COVID-19 preventive practices.

Conclusion: The COVID-19 preventive practice is not sufficiently satisfactory among educated Ethiopians. Females, those with advanced age, those who believes presence of re-infection by COVID-19, those with good knowledge of symptoms, prevention methods, and self-protective knowhow had better preventive practice. Extensive public awareness raising focusing on young population and males is essential to fight further spread of the virus.

\section{Background}

Coronavirus disease 2019 (COVID-19) is one of the strain in the family of corona virus which affects upper respiratory tract (1) An acute respiratory disease, known as the novel coronavirus disease 2019 identified in late 2019. The pathogen responsible for COVID-19 is a member of the coronavirus family, the severe acute respiratory syndrome coronavirus 2 (SARS-CoV-2, also known as the COVID-19 virus (2). The epidemic of unknown acute respiratory tract infection broke out first in Wuhan, China, since 12 December 2019, possibly related to a seafood market but not yet confirmed $(3,4)$. Suggested ways of human to human transmission of the COVID-19 is through 
droplet, feco-oral, and direct contact and has an average incubation period of 2-14 days (5). The disease is characterized by fever, dry cough, fatigue, tiredness and difficulty of breathing (6).

Transmission of SARS occurs primarily among family members, including relatives and friends who have closely encountered patients or carriers of coronavirus (3). On March 17, 2020, the WHO reported that the number of confirmed cases reached 179, 111 and 7426 deaths, the number of confirmed cases in Africa since then been 577 cases (7). In Ethiopia, the first case was reported on $13^{\text {th }}$ March, 2020. On April 5, the number increased to 2 confirmed cases and 2 deaths (8). In response to the COVID-19 outbreak, the Ethiopian government temporarily shut down all schools and cancelled face to face education at higher education institutions. COVID-19 and its response can also be expected to evoke broader anxieties (9).

The elderly, individuals with serious chronic medical conditions such as heart disease, diabetes mellitus and lung disease are at a higher risk of COVID-19 related death. According to WHO report the case fatality rate in people with no chronic diseases was 1.4 percent, $13.2 \%$ for those with cardiovascular disease, $9.2 \%$ for diabetes, $8.4 \%$ for hypertension, $8.0 \%$ for chronic respiratory disease, and $7.6 \%$ for cancer (10). There is presently no vaccine or specific anti-viral drug regime used to treat critically ill patients. The management of patients mainly focuses on the provision of supportive care, e.g., oxygenation, ventilation, and fluid management. Combination treatment of low-dose systematic corticosteroids and anti-virals and atomization inhalation of interferon have been encouraged as part of critical COVID-19 management (11). There are also other treatment regimens recommended these days but not yet verified. The main treatment, however is supportive care.

The key components in prevention and control measures and procedures for COVID-19 includes policies and procedures (hand hygiene, staffing, Personal Protective Equipment), routine practices and environmental and housekeeping, transporting patients, screening and surveillance, investigations of outbreaks, frequently wash your hands with soap and water for at least 20 seconds, if no water use an alcohol-based hand rub with at least $60 \%$ alcohol ,always wash hands that are visibly soiled, education and training for health care workers, avoid touching eyes, nose, or mouth with unwashed hands point of entry controls, avoid close contact with people who are sick (12-14). It has paramount effect like depression, anxiety and stress among individuals (15). Old-style public health measures, isolation, social distancing, avoidance of hand shake and community containment, are some of effective methods to prevent a disease when vaccine is not available (16). Millions of people are using different social media to gather information about COVID-19. So knowing preventive practice and factors towards Covid-19 among educated Ethiopians can pay a great role in the prevention of the disease. Misinformation is a sign of an individual's failure to inspect and verify the information they are sharing. Ideally, people need to explore the evidence and use empathy before jumping to conclusions, especially where other people and cultures are concerned. One of the challenge in fight against COVID-19 is misinformation and lack of preventive practice. The battle against COVID-19 is still continuing globally. Assessing preventive practice is an important approach to tackle health problems like Covid-19 among individuals $(17,18)$. The lessons learned from the 2003 SARS outbreak indicate that good practice towards infectious diseases are related to the degree of fear among the population, which may complicate further efforts to prevent the spread of the disease $(19,20)$.

The primary objective of this current study is therefore to identify the self-reported preventive practice and associated factors towards Covid-19 among educated Ethiopians using an online data collection by employing "COVID-19 Snapshot Monitoring (COSMO): Monitoring knowledge, risk perceptions, preventive behaviours, and public trust in the current coronavirus outbreak" tool. 


\section{Methods}

\section{Study design, area and period}

This online based cross-sectional study design was employed on educated individuals who had been using social media (such as Facebook, electronic mail, and telegram) and currently residing in Ethiopia. The survey was carried out from March 25 to April 4/ 2020.

\section{Population and inclusion criteria}

All educated social media users living in Ethiopia and who are Ethiopian nationals were used as study population. We included all educated social media users who were volunteer to fill the survey.

\section{Sample size determination and sampling technique}

It was difficult to determine the minimum sample size for this study. We included all individuals who were volunteer to fill the online survey from March 25 to April 4/ 2020. It was practically difficult to get sufficient response rate in internet based studies and increasing the sample size was essential. So we let the online survey for 10 days active to allow more participants' involvement.

\section{Operational/term definitions}

- COVID-19: The novel coronavirus which causes coronavirus disease and discovered in December 2019 (2).

- Preventive Practice: Respondents were asked if they practiced 12 preventive practices (proper and frequent handwashing using soap and water, use of sanitizer in the absence of soap and water, staying at home while having cough/cold, not travelling to abroad or risky areas, covering mouth and nose while sneezing or coughing, avoid touching face, nose and mouth with unwashed hand, consumption of balanced diet, avoiding contact with someone infected or suspected, use of facemask, regular physical exercise, physical/social distancing and, self-quarantine) and those who scored the median and above ( $\geq 8$ out of 12 questions) were considered as having good preventive practice.

- Knowledge: Respondents were asked 27 questions (6 questions about identification of people at greater risk of COVID-19 (pregnant women, people with chronic heart problem, people with asthma, people with pneumonia, people with diabetes mellitus and elderly), 9 questions about symptoms of COVID-19 (fever, cough, shortness of breath, sore throat, runny or stuffy nose, muscle/body aches, headaches, fatigue/tiredness and diarrhoea), 12 questions about prevention methods of COVID-19 (mentioned above under preventive practice)). Those who have answered the median (22 out of the 27 questions) and above were considered as having good overall knowledge.

\section{Variables of the study}

\section{Dependent/ outcome variable}

Preventive practice about COVID-19

\section{Independent variables}


Socio-demographic variables (sex, age, educational status, profession), presence of under-18 years children in house, source of information, self-rated overall health condition, history of psychiatric disease, knowledge about symptoms, prevention methods and people at higher risk, perceived susceptibility, perceived severity, perception about re-infection by COVID-19, self-rated awareness about COVID-19, primary source of information, and accepting authorities' recommendations to prevent COVID-19

\section{Data collection instrument}

We used a revised Germany COVID-19 Snapshot Monitoring (COSMO) questionnaire (21) containing sociodemographic variables, knowledge, attitude, and practice about COVID-19 symptoms, transmission routes, incubation period, prevention methods, and misconceptions. The primary variable of interest in this study was preventive practice about COVID-19. The knowledge, attitude and practice were measured as a composite variable computing the responses given for each knowledge, attitude and practice questions respectively.

\section{Data processing and analysis}

As this was an online data collection in the form of CSV (excel file), there was no need of data entry. The excel form data were imported into SPSS version 25 for statistical analysis. All assumptions for binary logistic regression were checked. To determine predictor variables for preventive practice, a binary logistic regression model was fitted. In multivariable binary logistic regression, variables were considered as significant at a $p$-value < 0.05 . Hosmer and Lemeshow goodness- of -fit test ( $p>0.05)$ was used to check model fitness. Results were presented using descriptive and inferential statistics.

\section{Results}

\section{Characteristics of study participants}

In the current study 528 respondents participated. Four hundred and twenty-six (80.7\%) were males and the mean age of the study participants was $33.2( \pm 7.4)$ years. Above one-third, $183 / 528(34.7 \%)$ of the participants had a health related profession. Two hundred and thirty-two (43.9\%) respondents had at least one child below age 18 years. Most of the study participants $(170 / 528,32.2 \%)$ reported health and health-related institutions as their primary source of information regarding COVID-19 followed by Facebook (138/528, 26.1\%). Majority (421/528, $79.7 \%$ ) of the respondents attended Bachelor degree and above education (table 1).

Table 2 shows the study participants' overall knowledge, knowledge about groups at high risk to COVID-19, symptoms of the disease, methods of prevention, vaccine none availability, transmission routes, re-infection and incubation period. Overall, above half $(295 / 528,55.9 \%)$ of the study subjects were knowledgeable about COVID-19. One hundred and eighty-three (34.7\%) had poor knowledge about people at risk of COVID-19 infection. About $55.3 \%(292 / 528)$ and $57.8 \%$ (305/528) had good knowledge regarding symptoms and prevention methods of COVID-19, respectively. The three mostly mentioned symptoms by respondents were fever $(96.8 \%, 511 / 528)$, shortness of breath $(94.3 \%, 498 / 528)$ and cough $(94.1 \%, 497 / 528)$. Nine out of ten $(90 \%, 475 / 528)$ respondents know that physical/social distancing can help prevent the spread of COVID-19. Almost all (515/520, 99.04\%) know that the disease has no vaccine for prevention or drug developed for treatment yet. Ninety seven point three percent of the respondents know that the disease is transmissible from person to person. While $20.8 \%(110 / 528)$ reported that they did not know whether a person who has recovered from the disease is immune to COVID-19 or not majority $(346 / 528,65.5 \%)$ reported that COVID-19 can re-infect a person who recovered from the illness. 
Almost all $(500 / 528,94.7 \%)$ respondents reported that the incubation period for the development of symptoms from the time of infection is 14 days.

Table 3 depicts the perception of the respondents regarding probability of getting infected by, susceptibility to, severity if infected with, and acceptance of governmental authority's recommendation regarding COVID-19. Only one hundred and eighty-one (34.3\%) respondents believe that their probability of getting infected is extremely likely. When respondents were asked how severe would contracting the COVID-19 be for them, about two-third $(350 / 528,66.3 \%)$ believe that it would be somewhat severe. Only one-fifth $(109 / 528,20.6 \%)$ and a few number of respondents $(22 / 528,4.2 \%)$ believe that avoiding COVID-19 infection is easy and extremely easy, respectively. While asked whether they follow the recommendations from authorities in their country to prevent spread of COVID-19, only $32 \%(169 / 528)$ responded that they were most likely to adhere to the recommendations. When asked whether they know how to protect themselves from COVID-19, ninety-five participants (18\%) responded that they know very much and ten (1.9\%) reported that they do not have the know-how at all.

Table 4 shows COVID-19 preventive practice reported by study participants. Overall above half $(285 / 528,54 \%)$ of the respondents had good COVID-19 preventive practice. About nine out of ten $(469 / 528,88.8 \%)$ study subjects reported that they were washing their hands for 20 seconds at 20 minutes intervals. Seventy-five percent (397/528) respondents reported that they have avoided touching their eyes, nose, and mouth with unwashed hands. Two hundred and sixty (49.2\%) reported that they have ensured balanced diet to protect themselves from COVID-19 infection. Seventy-three (13.8\%) reported that they have avoided consuming meat to protect themselves from COVID-19. About two-fifth $(211 / 528,40 \%)$ reported that they were wearing facemasks. Above one-fourth (139/528, $26.3 \%$ ) reported that they were consuming a mixture of Ruta chalepensis, ginger, lemon, garlic and honey to protect themselves from COVID-19. Only $72.9 \%$ (385/528) and $36.2 \%(191 / 528)$ reported that they practiced physical/social distancing and self-quarantine, respectively.

Table 5 shows factors associated with COVID-19 prevention practice. During the bivariable binary logistic regression, sex, age, type of profession, self-rated physical health problem, having a child below 18 years, self-rated awareness about COVID-19, knowledge about people at higher risk of the disease, knowledge of symptoms, prevention methods and re-infection, perceived susceptibility, perceived probability of getting infected, perceived severity, perceived self-protection knowhow, and acceptance of authorities' recommendations were variables with $\mathrm{p}$-value $<0.2$. These variables were candidates for the final multivariable binary logistic regression analysis. Variables with $\mathrm{p}$-value $<0.05$ were declared as significantly associated with the outcome at the final model. Being female, higher age, knowledge of symptoms, knowledge of prevention methods, knowledge of re-infection, and perceived self-protection knowhow were significantly associated with COVID-19 prevention practice.

Females had 2-fold better adjusted odds of COVID-19 prevention practice as compared to males [AOR: $2.00 ; 95 \% \mathrm{Cl}$ $(1.14,3.50)]$.

Respondents aged 33-37 years and 38-72 years had 1.99-fold [AOR: 1.98; 95\% Cl (1.01, 3.87)] and 2.60-fold [AOR: $2.60 ; 95 \% \mathrm{Cl}(1.33,5.10)]$ better COVID-19 preventive practice as compared to those aged below 28 years, respectively.

Respondents who have good knowledge of symptoms were 2.82 times [AOR: $2.82 ; 95 \% \mathrm{Cl}(1.85,4.31)$ ] and those with good knowledge of prevention methods were 4.55 times [AOR: $4.55 ; 95 \% \mathrm{Cl}(2.92,7.10)$ ] more likely to report 
better prevention practice as compared to those who have poor knowledge of symptoms and prevention methods, respectively.

Study participants who reported to have sufficient knowhow to protect themselves from COVID-19 had 1.83 times [AOR: $1.83 ; 95 \% \mathrm{Cl}(1.14,2.96)]$ better adjusted odds of self-reported prevention practice as compared to those who reported lack of self-protection knowhow.

Respondents who believe that after a person has recovered from the disease, he/she has chance of re-infection had 1.86 [AOR: $1.86 ; 95 \% \mathrm{Cl}(1.03,3.38)]$ times better odds of prevention practice as compared to those who believe that a person after recovery will be immune to COVID-19.

\section{Discussion}

To the best of our knowledge, this study which aimed to assess the self-reported prevention practice towards COVID-19 among Ethiopians is the first in the country. In this study, 54\% [95\% Cl (49.6, 58.5\%)] educated Ethiopians had good self-reported prevention practice towards COVID-19 in the early stage of the outbreak. The self-reported prevention practice towards COVID-19 was good in that $88.8 \%$ of the participants wash their hands for at least 20 seconds in 20 minutes interval, 80.5\% avoid touching their eyes, nose, and mouth with unwashed hands, and $72.9 \%$ practice physical distancing. The possible explanation for this high practice could be the study participants were educated and the first coronavirus case was reported in Ethiopia on 13 March (after 2 months since the first case of COVID-19 was reported from China) and it may increase the dissemination of information which helped them to practice preventive measures. People should practice possible preventive strategies to protect themselves and others from infection by washing hands or using an alcohol based rub frequently and not touching the face, practicing physical distancing where possible and self-isolate if they start to show symptoms such as fever, tiredness, dry cough, shortness of breath, sore throat, and body aches $(22,23)$.

The adjusted odds of self-reported prevention practice towards COVID-19 was two-fold higher among female respondents when compared with males. The findings of this study is supported by other study (24). It might be because mostly females participate in childcare, food preparation and other tasks compared with males. Therefore, preventive measures are more likely to be practiced better among females to protect themselves and others from infection.

Respondents aged 33-37 years and 38-72 years had 1.98 and 2.6-fold better practice of COVID-19 preventive measures as compared to those aged below 28 years respectively. Studies on COVID-19 published so far revealed the case fatality rate of COVID-19 close to $15 \%$ in patients over the age of 80 in contrast to the average overall case fatality rate of $2.3 \%$ (25) and evidences from China suggested that paediatrics COVID-19 cases might be less severe than cases in adults and that children might experience different symptoms than do adults (26-28). Because of the above scenario, older participants may have better practice of COVID-19 preventive measures than the younger individuals.

When compared respondents who have poor knowledge of COVID-19 symptoms and prevention methods, who have good knowledge of COVID-19 symptoms and prevention methods were 2.82 times and 4.55 times more likely to report better prevention practice respectively. Knowledge of respondents on people at risk group were elderly above 60 years 465 (88.1\%), people with pneumonia 412 (78.0\%), people with diabetes mellitus 396 (75.0\%), people with asthma 396 (75.0\%), and people with chronic heart disease 375 (72.0\%) from highest to lowest 
respectively. Knowledge on symptoms of COVID 19 shortness of breath 498 (94.3\%), sore throat 447 (84.7\%), headache 415 (78.6\%), and fatigue 406(76.9\%). Knowledge about coronavirus disease (COVID-19) sign and symptoms, transmission, treatment, and how to prevent infection will increase prevention practice of an individuals and they might be implement the key messages of the guideline include causes, how to choose and wear face masks, proper hand washing habits, preventive measures at different locations (e.g., at home, on public transportation, and in public space), disinfection methods, and medical observation at home $(24,29)$.

Study participants who reported to have sufficient knowhow to protect themselves from COVID-19 had 1.83 times higher better self-reported prevention practice as compared to their counterparts. Knowing the mode of transmission, the prevention mechanism of COVID 19, and the ways of protecting themselves by practicing physical distancing and self-isolation where possible can improve prevention practice.

Respondents who believe that after a person has recovered from the disease, he/she has chance of re-infection had 1.86 times higher better prevention practice as compared to their counterparts. Experts unsure if 'cured' COVID19 patients are re-infected or relapsed and U.S. experts in a World Health Organization delegation that visited China in February. He said Chinese experts told the visitors that there were no examples of people who became "reinfected"(30). However, there are contradictory reports regarding re-infection which supported the presence of reinfection (31).

\section{Limitations Of The Study}

This study was undertaken among educated Ethiopians within a very short period. As this is a cross-sectional study it does not show cause effect relationship. The lack of sufficient literature made the comparison of results difficult.

\section{Conclusion}

The COVID-19 preventive practice among educated Ethiopians is not sufficiently satisfactory. Females, those with advanced age, those who believes presence of re-infection by COVID-19, those with good knowledge of symptoms, prevention methods, and self-protective knowhow had better preventive practice. Extensive public awareness raising focusing on young population and males is essential to fight further spread of the virus. Further study on the knowledge, attitude and practice of COVID-19 prevention among uneducated Ethiopians is essential.

\section{Tables}

Table 1: Sociodemographic characteristics of the study participants in Ethiopia $(n=528)$ 


\begin{tabular}{|c|c|c|c|}
\hline Variable & Categories & $\begin{array}{l}\text { Frequency } \\
\text { (n) }\end{array}$ & $\begin{array}{l}\text { Percentage } \\
(\%)\end{array}$ \\
\hline \multirow[t]{2}{*}{ Sex } & Male & 426 & 80.7 \\
\hline & Female & 102 & 19.3 \\
\hline \multirow[t]{4}{*}{ Age in years } & $\leq 28$ & 135 & 25.6 \\
\hline & $29-32$ & 151 & 28.6 \\
\hline & $33-37$ & 115 & 21.8 \\
\hline & $38-72$ & 127 & 24.1 \\
\hline \multirow[t]{2}{*}{ Education } & Diploma and below & 107 & 20.3 \\
\hline & Degree and above & 421 & 79.7 \\
\hline \multirow[t]{2}{*}{ Type of profession } & Health-related & 183 & 34.7 \\
\hline & Not health-related & 345 & 65.3 \\
\hline \multirow[t]{2}{*}{ Have child under 18 years } & Yes & 232 & 43.9 \\
\hline & No & 296 & 56.1 \\
\hline \multirow[t]{6}{*}{ Primary source of information } & $\begin{array}{l}\text { Health and related } \\
\text { institutions }\end{array}$ & 170 & 32.2 \\
\hline & Facebook & 138 & 26.1 \\
\hline & Government report & 87 & 16.5 \\
\hline & TV/radio & 84 & 15.9 \\
\hline & Telegram & 26 & 4.9 \\
\hline & others & 23 & 4.4 \\
\hline \multirow[t]{2}{*}{ Self-rated overall health condition } & Poor & 7 & 1.3 \\
\hline & Good & 521 & 98.7 \\
\hline \multirow[t]{2}{*}{ Self-rated physical health problem } & No & 457 & 88.6 \\
\hline & Yes & 71 & 13.4 \\
\hline \multirow[t]{2}{*}{ Self-reported history of psychiatric disorder } & No & 505 & 95.6 \\
\hline & Yes & 23 & 4.4 \\
\hline \multirow[t]{2}{*}{ Self-rated knowledge about COVID-19 } & Poor & 22 & 4.2 \\
\hline & Good & 506 & 95.8 \\
\hline \multirow{2}{*}{$\begin{array}{l}\text { Self-rated knowledge about COVID-19 } \\
\text { transmission }\end{array}$} & Poor & 25 & 4.7 \\
\hline & Good & 503 & 95.3 \\
\hline
\end{tabular}


Table 2: Participants' knowledge of risky groups, symptoms, prevention methods and preventive practice of COVID19 among educated Ethiopians ( $n=528)$ 


\begin{tabular}{|c|c|c|c|}
\hline Variable & Categories & (n) & $(\%)$ \\
\hline \multirow{2}{*}{$\begin{array}{l}\text { Overall knowledge about COVID- } \\
19\end{array}$} & Poor & 233 & 44.1 \\
\hline & Good & 295 & 55.9 \\
\hline \multirow{11}{*}{$\begin{array}{l}\text { Knowledge of people at risk } \\
\text { group }\end{array}$} & Poor & 183 & 34.7 \\
\hline & Good & 345 & 65.3 \\
\hline & Do not know & 29 & 5.5 \\
\hline & Elderly above 60 years & 465 & 88.1 \\
\hline & Pregnant women & 230 & 43.6 \\
\hline & Infants & 98 & 18.6 \\
\hline & Children under age five & 100 & 18.9 \\
\hline & People with chronic heart disease & 375 & 72.0 \\
\hline & People with Diabetes mellitus & 396 & 75.0 \\
\hline & People with pneumonia & 412 & 78.0 \\
\hline & People with asthma & 396 & 75.0 \\
\hline \multirow[t]{11}{*}{ Knowledge on symptoms } & Poor & 236 & 44.7 \\
\hline & Good & 292 & 55.3 \\
\hline & Fever & 511 & 96.8 \\
\hline & Cough & 497 & 94.1 \\
\hline & Shortness of breath & 498 & 94.3 \\
\hline & Sore throat & 447 & 84.7 \\
\hline & Runny/stuffy nose & 136 & 25.8 \\
\hline & Muscle pain & 307 & 58.1 \\
\hline & Headache & 415 & 78.6 \\
\hline & Fatigue & 406 & 76.9 \\
\hline & Diarrhoea & 173 & 32.8 \\
\hline \multirow{6}{*}{$\begin{array}{l}\text { Knowledge of prevention } \\
\text { methods of COVID- } 19\end{array}$} & Poor & 223 & 42.2 \\
\hline & Good & 305 & 57.8 \\
\hline & Hand washing for 20 seconds & 506 & 95.8 \\
\hline & $\begin{array}{l}\text { Avoiding touching your eyes, nose, and mouth with } \\
\text { unwashed hands }\end{array}$ & 474 & 89.8 \\
\hline & $\begin{array}{l}\text { Use of disinfectants to clean hands when soap and water } \\
\text { is not available for washing hands }\end{array}$ & 499 & 94.5 \\
\hline & $\begin{array}{l}\text { Staying home when you are sick or when you have a cold } \\
\text { Page } 11 / 19\end{array}$ & 456 & 86.4 \\
\hline
\end{tabular}




\begin{tabular}{|c|c|c|c|}
\hline & Not travelling abroad & 486 & 92.0 \\
\hline & Covering your mouth when you cough & 490 & 92.8 \\
\hline & Ensuring a balanced diet & 397 & 75.2 \\
\hline & Avoiding close contact with someone who is infected & 499 & 94.5 \\
\hline & Avoiding eating meat & 114 & 21.6 \\
\hline & Wearing facemask & 424 & 80.3 \\
\hline & Regular physical exercise & 309 & 58.5 \\
\hline & $\begin{array}{l}\text { Taking mixture of Ruta chalepensis, ginger, lemon, garlic } \\
\text { and honey }\end{array}$ & 139 & 26.3 \\
\hline & Taking Areqi (local beer) & 32 & 6.1 \\
\hline & Physical/social distancing & 475 & 90.0 \\
\hline & Self-quarantine & 357 & 67.6 \\
\hline \multirow{11}{*}{$\begin{array}{l}\text { Knowledge of availability of } \\
\text { vaccine and drugs }(n=520)\end{array}$} & No vaccine and drug & 515 & 99.04 \\
\hline & Yes, there is vaccine and drug & 5 & 0.96 \\
\hline & \multicolumn{3}{|l|}{ Knowledge of transmission route } \\
\hline & Do not know & 1 & 0.2 \\
\hline & No transmission at all & 7 & 1.3 \\
\hline & Only from animal to person transmission & 6 & 1.1 \\
\hline & Person to person transmission & 514 & 97.3 \\
\hline & \multicolumn{3}{|l|}{ Knowledge of re-infection } \\
\hline & Do not know & 110 & 20.8 \\
\hline & No re-infection & 72 & 13.6 \\
\hline & Yes re-infection & 346 & 65.5 \\
\hline \multirow[t]{4}{*}{ Knowledge of incubation period } & Do not know & 3 & 0.6 \\
\hline & 3 days & 18 & 3.4 \\
\hline & 7 days & 7 & 1.3 \\
\hline & 14 days & 500 & 94.7 \\
\hline
\end{tabular}

Table 3: Attitude towards COVID-19 among educated Ethiopians, 2020 ( $n=528)$. 


\begin{tabular}{|c|c|c|}
\hline Variable & number (n) & Percentage (\%) \\
\hline \multicolumn{3}{|c|}{ Probability of getting infected } \\
\hline Extremely likely & 181 & 34.3 \\
\hline Somewhat likely & 302 & 57.2 \\
\hline Unlikely & 37 & 7.0 \\
\hline Extremely unlikely & 8 & 1.5 \\
\hline \multicolumn{3}{|l|}{ Severity if infected } \\
\hline Very sever & 141 & 26.7 \\
\hline Somewhat sever & 350 & 66.3 \\
\hline Not sever & 32 & 6.1 \\
\hline Not at all sever & 5 & 0.9 \\
\hline \multicolumn{3}{|l|}{ Susceptibility } \\
\hline Extremely susceptible & 47 & 8.9 \\
\hline Highly susceptible & 116 & 22.0 \\
\hline Somewhat susceptible & 335 & 63.4 \\
\hline Not at all susceptible & 30 & 5.7 \\
\hline \multicolumn{3}{|l|}{ Self-protection know-how } \\
\hline Very so much & 95 & 18.0 \\
\hline Yes & 241 & 45.6 \\
\hline Somewhat yes & 182 & 34.5 \\
\hline Not at all & 10 & 1.9 \\
\hline \multicolumn{3}{|c|}{ How hard is avoiding COVID-19 infection } \\
\hline Extremely easy & 22 & 4.2 \\
\hline Easy & 109 & 20.6 \\
\hline Somewhat difficult & 319 & 60.4 \\
\hline Extremely difficult & 78 & 14.8 \\
\hline \multicolumn{3}{|c|}{ How likely do you accept recommendation from authorities } \\
\hline Not at all & 3 & 0.6 \\
\hline Somewhat yes & 72 & 13.6 \\
\hline Yes & 284 & 53.8 \\
\hline Very so much & 169 & 32.0 \\
\hline
\end{tabular}


Table 4: Preventive practice of COVID-19 among educated Ethiopians, 2020 ( $n=528)$

Variable

(n)

Overall preventive practice of COVID-19

\begin{tabular}{lcc}
\hline Poor & 243 & 46 \\
\hline Good & 285 & 54 \\
\hline Hand washing for 20 seconds at 20 minutes intervals & 469 & 88.8 \\
\hline Avoiding touching your eyes, nose, and mouth with unwashed hands & 425 & 80.5 \\
\hline Use of disinfectants to clean hands when soap and water is not available for washing hands & 397 & 75.2 \\
\hline Staying home when you are sick or when you have a cold & 237 & 44.9 \\
\hline Not travelling abroad & 352 & 66.7 \\
\hline Covering your mouth when you cough & 370 & 70.1 \\
\hline Ensuring a balanced diet & 260 & 49.2 \\
\hline Avoiding close contact with someone who is infected & 337 & 63.8 \\
\hline Avoiding eating meat & 73 & 13.8 \\
\hline Wearing facemask & 211 & 40.0 \\
\hline Regular physical exercise & 160 & 30.3 \\
\hline Taking mixture of Ruta chalepensis, ginger, lemon, garlic and honey & 139 & 26.3 \\
\hline Taking Areqi (local bear) & 38 & 7.2 \\
\hline Physical/social distancing & 385 & 72.9 \\
\hline Self-quarantine & 361 & 36.2
\end{tabular}

Table 5: Factors associated with COVID-19 prevention practice among Ethiopians $(n=528)$ 
COVID-19 prevention practice

COR $95 \% \mathrm{Cl}$

AOR $95 \% \mathrm{Cl}$

\begin{tabular}{|c|c|c|c|c|c|}
\hline \multicolumn{2}{|l|}{ Variables } & \multirow{2}{*}{$\begin{array}{l}\text { Poor (\%) } \\
34(14.0)\end{array}$} & \multicolumn{3}{|l|}{ Good (\%) } \\
\hline \multirow[t]{2}{*}{ Sex } & Female & & $68(23.9)$ & $1.93(1.22,3.03)^{\star \star}$ & $2.00(1.14,3.50)$ * \\
\hline & Male & $209(86.0)$ & $217(76.1)$ & 1 & 1 \\
\hline \multirow[t]{4}{*}{ Age } & $<28$ years & $74(30.5)$ & $61(21.4)$ & 1 & 1 \\
\hline & 29-32 years & 77(31.7) & $74(26.0)$ & $1.17(0.73,1.86)$ & $0.98(0.56,1.75)$ \\
\hline & $33-37$ years & $51(21.0)$ & $64(22.5)$ & $1.52(0.92,2.51)$ & $1.98(1.01,3.87)^{\star}$ \\
\hline & $38-72$ years & $41(16.9)$ & $86(30.2)$ & $\begin{array}{l}2.54(1.54 \\
4.21)^{\star \star \star}\end{array}$ & $2.60(1.33,5.10) * \star$ \\
\hline \multirow[t]{2}{*}{$\begin{array}{l}\text { Type of } \\
\text { profession }\end{array}$} & $\begin{array}{l}\text { Health- } \\
\text { related }\end{array}$ & $94(38.7)$ & $89(31.2)$ & $0.72(0.50,1.03)$ & $1.41(0.89,2.23)$ \\
\hline & $\begin{array}{l}\text { Not health- } \\
\text { related }\end{array}$ & $149(61.3)$ & 196(68.8) & 1 & 1 \\
\hline \multirow{2}{*}{$\begin{array}{l}\text { Self-rated } \\
\text { physical health } \\
\text { problem }\end{array}$} & No & $216(88.9)$ & $241(84.6)$ & 1 & 1 \\
\hline & Yes & $27(11.1)$ & $44(15.4)$ & $1.46(0.87,2.44)$ & $0.74(0.39,1.39)$ \\
\hline \multirow{2}{*}{$\begin{array}{l}\text { Have U-18 years } \\
\text { children }\end{array}$} & No & $145(59.7)$ & $151(53.0)$ & 1 & 1 \\
\hline & Yes & $98(40.3)$ & 134(47.0) & $1.31(0.93,1.86)$ & $1.09(0.68,1.74)$ \\
\hline \multirow{2}{*}{$\begin{array}{l}\text { Self-rated } \\
\text { awareness of } \\
\text { COVID-19 }\end{array}$} & No & $24(9.9)$ & $16(5.6)$ & 1 & 1 \\
\hline & Yes & 219(90.1) & $269(94.4)$ & $1.84(0.96,3.56)$ & $0.97(0.43,2.17)$ \\
\hline \multirow{2}{*}{$\begin{array}{l}\text { Knowledge of } \\
\text { people at higher } \\
\text { risk }\end{array}$} & Poor & $96(39.5)$ & $87(30.5)$ & 1 & 1 \\
\hline & Good & $147(60.5)$ & 198(69.5) & $1.49(1.04,2.13)^{\star}$ & $0.97(0.62,1.51)$ \\
\hline \multirow{2}{*}{$\begin{array}{l}\text { Knowledge of } \\
\text { symptoms }\end{array}$} & Poor & $145(59.7)$ & $91(31.9)$ & 1 & 1 \\
\hline & Good & $98(40.3)$ & 194(68.1) & $3.15(2.21,4.51)^{\star \star \star}$ & $2.82(1.85,4.31)^{\star \star \star}$ \\
\hline \multirow{2}{*}{$\begin{array}{l}\text { Knowledge of } \\
\text { prevention } \\
\text { method }\end{array}$} & Poor & $151(62.1)$ & $72(25.3)$ & 1 & 1 \\
\hline & Good & $92(37.9)$ & $213(74.7)$ & $4.86(3.35,7.04)^{\star \star \star}$ & $4.55(2.92,7.10)^{\star \star \star}$ \\
\hline \multirow{6}{*}{$\begin{array}{l}\text { Primary source of } \\
\text { information }\end{array}$} & Facebook & $67(27.6)$ & $71(24.9)$ & $1.41(0.82,2.44)$ & $1.41(0.72,2.73)$ \\
\hline & $\begin{array}{l}\text { Government- } \\
\text { report }\end{array}$ & $30(12.3)$ & $57(20)$ & $2.53(1.36,4.70)^{\star \star}$ & $2.00(0.96,4.15)$ \\
\hline & $\begin{array}{l}\text { Health and } \\
\text { health- } \\
\text { related } \\
\text { institutions }\end{array}$ & $72(29.6)$ & $98(34.4)$ & $1.82(1.07,3.08)^{\star}$ & $1.79(0.95,3.39)$ \\
\hline & Others* & $15(6.2)$ & $8(2.8)$ & $0.71(0.27,1.86)$ & $0.55(0.18,1.66)$ \\
\hline & Telegram & $11(4.5)$ & $15(5.3)$ & $1.82(0.75,4.43)$ & $1.78(0.62,5.04)$ \\
\hline & TV/radio & $48(19.8)$ & $36(12.6)$ & 1 & 1 \\
\hline
\end{tabular}




\begin{tabular}{|c|c|c|c|c|c|}
\hline \multirow[t]{3}{*}{$\begin{array}{l}\text { Knowledge of re- } \\
\text { infection }\end{array}$} & $\begin{array}{l}\text { No re- } \\
\text { infection }\end{array}$ & $41(16.9)$ & $31(10.9)$ & 1 & 1 \\
\hline & Do not know & $56(23.0)$ & $54(18.9)$ & $1.28(0.70,2.32)$ & $1.54(0.76,3.13)$ \\
\hline & $\begin{array}{l}\text { Yes re- } \\
\text { infection }\end{array}$ & $146(60.1)$ & $200(70.2)$ & $1.81(1.08,3.03)^{\star}$ & $1.86\left((1.03,3.38)^{*}\right.$ \\
\hline \multirow[t]{2}{*}{$\begin{array}{l}\text { Perceived } \\
\text { susceptibility }\end{array}$} & $\begin{array}{l}\text { Not } \\
\text { susceptible }\end{array}$ & 153(63.0) & $212(74.4)$ & $1.71(1.17,2.48)^{\star \star}$ & $0.86(0.48,1.54)$ \\
\hline & susceptible & $90(37.0)$ & $73(25.6)$ & 1 & 1 \\
\hline \multirow{2}{*}{$\begin{array}{l}\text { Perceived } \\
\text { probability of } \\
\text { getting infected }\end{array}$} & unlikely & $150(61.7)$ & 197(69.1) & $1.39(0.97,1.99)$ & $0.95(0.55,1.64)$ \\
\hline & likely & 93(383) & 88(30.9) & 1 & 1 \\
\hline \multirow[t]{2}{*}{ Perceived severity } & Not sever & $23(9.5)$ & $14(4.9)$ & 1 & 1 \\
\hline & Sever & $220(90.5)$ & 271(95.1) & $2.02(1.02,4.03)^{\star}$ & $2.06(0.91,4.70)$ \\
\hline \multirow{2}{*}{$\begin{array}{l}\text { Perceived self- } \\
\text { protection know- } \\
\text { how }\end{array}$} & No & $114(46.9)$ & 78(27.4) & 1 & 1 \\
\hline & Yes & 129(53.1) & 207(72.6) & $2.34(1.63,3.37)^{\star \star \star}$ & $1.83(1.14,2.96)^{\star}$ \\
\hline \multirow{2}{*}{$\begin{array}{l}\text { Acceptance of } \\
\text { authorities } \\
\text { recommendations }\end{array}$} & No & $48(19.8)$ & $27(9.5)$ & 1 & 1 \\
\hline & Yes & 195(80.2) & $258(90.5)$ & $2.35(1.42,3.90)^{\star}$ & $1.22(0.62,2.39)$ \\
\hline
\end{tabular}

$1=$ Reference group, $*$ Significant at $p<0.05, * * p<0.01, * * \star$ Significant at $p<0.001$, Hosmer and Lemeshow goodness of fit test $(p=0.881)$

\section{Abbreviations}

AOR: Adjusted Odds Ratio Cl: Confidence Interval COR: Crude Odds Ratio EPI Info: Epidemiological Information SPSS: Statistical Package for Social Sciences

\section{Declarations}

\section{Ethical approval and consent to participate}

Ethical approval was obtained from the Ethical Review Committee of Environmental and Occupational Health and Safety department, the University of Gondar. Respondents were communicated via social media. After explaining the purpose of the study, respondents were asked to fill and submit their responses. Any potential identifiers were eliminated to ascertain confidentiality.

\section{Consent for publication}

Not applicable

\section{Availability of data and materials}

The dataset is accessible at the corresponding author upon a reasonable request.

\section{Competing interests}


The authors declare that they have no competing interests

\section{Funding}

No funding agent

\section{Authors' contributions}

HD participated as a lead investigator in conceptualization, proposal development, analysis and write up of the manuscript, KA, DT, AMA, ZA, BD, DEA and JA write various parts of the proposal and the manuscript, help in analysis and commented the draft and final manuscript. All authors reviewed and approved the final manuscript.

\section{Acknowledgments}

The authors are grateful for study participants, University of Gondar, individuals and associations who helped in dissemination of the data collection tool. We are grateful to Hakim-page, Journalists (Ayalew Menber, Metages Ayelegn, Amdework Nigussie, Solomon Muche), Natnael Mekonnen, Deacon Birhanu Admas Aniley and Kesis Dejene Shiferaw for their unreserved support to make this research work a reality.

\section{References}

1. Joseph T. COVID-19: International pulmonologist's consensus group on COVID-19; 2020 [Available from: https://www.unah.edu.hn/dmsdocument/9674-consenso-internacional-de-neumologos-sobre-covid-19version-ingles.

2. Lipsitch M, Swerdlow DL, Finelli L. Defining the epidemiology of Covid-19-studies needed. New England Journal of Medicine. 2020.

3. Guo Y-R, Cao Q-D, Hong Z-S, Tan Y-Y, Chen S-D, Jin H-J, et al. The origin, transmission and clinical therapies on coronavirus disease 2019 (COVID-19) outbreak-an update on the status. Military Medical Research. 2020;7(1):1-10.

4. Paraskevis D, Kostaki EG, Magiorkinis G, Panayiotakopoulos G, Sourvinos G, Tsiodras S. Full-genome evolutionary analysis of the novel corona virus (2019-nCoV) rejects the hypothesis of emergence as a result of a recent recombination event. Infection, Genetics and Evolution. 2020;79:104212.

5. Bhagavathula AS, Aldhaleei WA, Rahmani J, Mahabadi MA, Bandari DK. Novel Coronavirus (COVID-19) Knowledge and Perceptions: A Survey on Healthcare workers. medRxiv. 2020.

6. Wu Z, McGoogan JM. Characteristics of and important lessons from the coronavirus disease 2019 (COVID-19) outbreak in China: summary of a report of 72314 cases from the Chinese Center for Disease Control and Prevention. Jama. 2020.

7. WHO. Coronavirus disease (COVID-2019) situation reports: Situation report - 57. 2020.

8. apanews.net. Ethiopia reports sixth case of coronavirus. . 2020.

9. Leach M. Echoes of Ebola: social and political warnings for the COVID-19 response in African settings. Echoes. 2020.

10. Canady VA. Mental health groups providing support, education in wake of COVID-19. Mental Health Weekly. 2020;30(11):1-3. 
11. Liu Y, Li J, Feng Y. Critical care response to a hospital outbreak of the 2019-nCoV infection in Shenzhen, China. BioMed Central; 2020.

12. Liu C, Zhou Q, Li Y, Garner LV, Watkins SP, Carter LJ, et al. Research and Development on Therapeutic Agents and Vaccines for COVID-19 and Related Human Coronavirus Diseases. ACS Publications; 2020.

13. Ono SJ. COVID-19 and Faculty of Medicine Preparedness.

14. Bai Y, Yao L, Wei T, Tian F, Jin D-Y, Chen L, et al. Presumed asymptomatic carrier transmission of COVID-19. Jama. 2020.

15. Wang C, Pan R, Wan X, Tan Y, Xu L, Ho CS, et al. Immediate psychological responses and associated factors during the initial stage of the 2019 coronavirus disease (COVID-19) epidemic among the general population in china. International Journal of Environmental Research and Public Health. 2020;17(5):1729.

16. Wilder-Smith A, Freedman D. Isolation, quarantine, social distancing and community containment: pivotal role for old-style public health measures in the novel coronavirus (2019-nCoV) outbreak. Journal of travel medicine. 2020;27(2):taaa020.

17. Ajilore K, Atakiti I, Onyenankeya K. College students' knowledge, attitudes and adherence to public service announcements on Ebola in Nigeria: Suggestions for improving future Ebola prevention education programmes. Health Education Journal. 2017;76(6):648-60.

18. Tachfouti N, Slama K, Berraho M, Nejjari C. The impact of knowledge and attitudes on adherence to tuberculosis treatment: a case-control study in a Moroccan region. Pan African Medical Journal. 2012;12(1).

19. Person B, Sy F, Holton K, Govert B, Liang A. Fear and stigma: the epidemic within the SARS outbreak. Emerging Infectious Diseases. 2004;10(2):358.

20. Zhong B-L, Luo W, Li H-M, Zhang Q-Q, Liu X-G, Li W-T, et al. Knowledge, attitudes, and practices towards COVID-19 among Chinese residents during the rapid rise period of the COVID-19 outbreak: a quick online cross-sectional survey. Int J Biol Sci. 2020;16(10):1745-52.

21. Betsch C, Wieler L, Bosnjak M, Ramharter M, Stollorz V, Omer S, et al. Germany COVID-19 Snapshot MOnitoring (COSMO Germany): Monitoring knowledge, risk perceptions, preventive behaviours, and public trust in the current coronavirus outbreak in Germany. 2020.

22. Plan for international. What is coronavirus / COVID-19? 2020 [cited 2020 10. April]. Available from: https://plan-international.org/emergencies/covid-19-faqs-girls-women

23. Organization WH. Key Messages and Actions for COVID-19 Prevention and Control in Schools. 2020.

24. Zhong B-L, Luo W, Li H-M, Zhang Q-Q, Liu X-G, Li W-T, et al. Knowledge, attitudes, and practices towards COVID-19 among Chinese residents during the rapid rise period of the COVID-19 outbreak: a quick online cross-sectional survey. International Journal of Biological Sciences. 2020;16(10):1745.

25. Healthline. Older or with underlying conditions at greatest risk 2020 [cited 2020 April, 10]. Available from: https://www.healthline.com/health-news/what-older-people-with-chronic-conditions-need-to-know-aboutcovid-19.

26. Center of communical disease control. Coronavirus Disease 2019 in Children - United States, February 12April 2, 20202020 [cited 2020 April, 2020]. Available from: https://www.cdc.gov/mmwr/volumes/69/wr/mm6914e4.htm.

27. Lu X, Zhang L, Du H, Zhang J, Li YY, Qu J, et al. SARS-CoV-2 Infection in Children. New England Journal of Medicine. 2020. 
28. Dong Y, Mo X, Hu Y, Qi X, Jiang F, Jiang Z, et al. Epidemiology of COVID-19 Among Children in China. Pediatrics. 2020:e20200702.

29. Adhikari SP, Meng S, Wu Y-J, Mao Y-P, Ye R-X, Wang Q-Z, et al. Epidemiology, causes, clinical manifestation and diagnosis, prevention and control of coronavirus disease (COVID-19) during the early outbreak period: a scoping review. Infectious diseases of poverty. 2020;9(1):1-12.

30. Snopses. Can People Who Recover from COVID-19 Become Reinfected? 2020 [cited 2020 April 10,]. Available from: https://www.snopes.com/fact-check/covid-19-reinfection/.

31. Kelly S. Covid-19 re-infection rates increase 2020 [cited 2020 April 9]. Available from: https://thethaiger.com/coronavirus/cv19-asia/cv19-thailand/covid-19-reinfection-rates-increase. 